\title{
Diversity Studies in Plant and Ratoon Crops for Selection of Profitable Sugarcane Genotypes Tolerant to Water Logging
}

\author{
Balwant Kumar ${ }^{1 *}$, D. N. Kamat ${ }^{1}$ and S. P. Singh ${ }^{2}$ \\ ${ }^{1}$ Plant Breeding and Genetics, S.R.I., Dr.R.P.C.A.U., Pusa, Bihar, India \\ ${ }^{2}$ Agriculture Economist, S.R.I. R.P.C.A.U., Pusa, Bihar, Samastipur (Pin-848 125), India \\ *Corresponding author
}

\section{Keywords}

Cluster, genetic diversity, water logging tolerant, profitable genotypes, sugarcane plant and ratoon

\section{Article Info}

Accepted:

20 August 2019

Available Online:

10 September 2019

\section{A B S T R A C T}

Studies on genetic divergence in sugarcane plant and ratoon crops involving sixteen genotypes planted at RAU Pusa Farm, Samastipur, Bihar during 2012-13 and their consecutive ratoon during 2013-14 under low land area with water-stagnation 2 to 3 months to select profitable genotypes tolerant to water logging. Cane yield of plant crop was higher than the ratoon while for juice quality traits of ratoon crop showed better. All genotypes differed significantly with regard to the traits studied and displayed distinct marked divergence, grouped into five clusters for both crops following Tocher's method. only Cluster I and II had more than one genotypes while Cluster III, IV and V were monogenotypic. In plant crop maximum inter cluster distance was observed between cluster IV and V (5763.19) followed by cluster III \& V(4350.43), Cluster I \& V (2297.2) and between Cluster II \& IV(1835.66) while in ratoon crop between cluster II and V (1050.77), cluster III \& V (817.02), Cluster III \& IV(623.84), Cluster II \& IV (567.85), Cluster I \& V (419.80) and between Cluster I \& II(319.39). In plant crop highest contribution in the manifestation of genetic divergence was exhibited by cane yield (52.50) followed by CCS per cent at harvest (20.83), pol \% in juice at 11 month stage (9.17) while in ratoon crop pol \% in juice 9 month stage (45.0) had highest followed by brix 11 month(15.0), CCS per cent at harvest (10.83), purity \% at 11 month (8.33), single cane weight (7.50). Profitable offspring will be obtained after crossing between the genotypes of Cluster I and II with Cluster V. Maximum average cane yield (91.83 t/ha) and CCS t/ha (10.60 t/ha) were recorded in CoP 09437 followed by BO 154, CoP 2061, BO 155 and CoX 07067. Minimum average yield gap between plant and ratoon crop was observed in CoP 09437(losses 8.93\%) and its ratoon contributed highest $47.7 \%$ towards average cane yield, 26.7 and $17.4 \%$ higher cane yield 45.80 and $41.15 \%$ higher CCS t/ha than BO91 \& BO147, respectively followed by BO 154 and CoP 2061. Selection on the basis of percentage increase over checks and minimum loss in cane yield and CCS t/ha CoP 09437, BO 154 and CoP 2061 were found profitable one to cultivate under low land (water logging) sugarcane growing areas which will enhance productivity and sugar recovery. 


\section{Introduction}

Improvements in cane and sugar yield per unit area are two most important profitable objectives of sugarcane breeding programme. The farmers are being paid for their raw material on the basis of cane weight, where as the interest of sugar mill management lies on sugar recovery per unit cane weight. Therefore cane yield as well as sugar recovery are important components for making the variety commercially viable even under water logging. Cane and sugar yield are influenced by many factors, including changing climatic scenario, waterlogged, soil composition and structure, irrigation and drainage requirements, varieties, pests and diseases, management skill, labour availability and harvesting methods among them water logged area is major constrain because most of the varieties are not performing well under such condition. India has produced 376 million tonnes of sugarcane at a productivity level of $79.65 \mathrm{t} / \mathrm{ha}$ from $4.73 \mathrm{~m}$ ha area in $2017-18$ (Indian Sugar-2018) while productivity of this crop in Bihar was low (50t/ha). Both plant and Ratoon crops of sugarcane contributes in average productivity. Good ratooning ability of cane cultivars is an essential pre-requisite determined by a number of factors. Various plant characters were associated with ratooning ability of sugarcane varieties and successes of the variety depend on its ability to give more profitable ratoons (Chapman et al., 1992). Moreover, excess rainfall during late summer and monsoon quite often creates flooding problem and grower have no option but to use flood affected sugarcane ratoon. However, information is lacking on the effect of water. So, an effort has been made to comparative study to potential of commercial ratoon variety leading to higher yield and sugar yield per hectare. The aim of the experiment is to study the tolerance behavior of plant crop as well as its ratoon under water logging condition with high cane and sugar yield. As we know that all sugarcane cultivar in the present scenario under cultivation have wide genetic background viz, twenty $S$. officinarum, two S. spontaneum, and a couple of $S$. barberi and $S$. sinense clones which may be a major threat to the sugarcane productivity and demands concerted efforts to utilize new genetic diversity (Walker,1987; Nair 2012). Clonal selection of high cane and sugar yielder profitable clones bearing stress tolerance and its utilization in sugarcane improvement programme is an important but rather difficult task for plant breeders. Diversity analysis helps in assessing the nature of diversity in order to identified and select the genetically diverse clones for their use in sugarcane breeding programme and the diversity of parents is always emphasized. More diverse the parent within a reasonable range, better the chances of improving economic characters under consideration in the resulting profitable offspring. Sugarcane cultivation and its proper production in Bihar is facing several challenges and most of the sugarcane industries are closed since last three decade due to various reason, among them major is 35-40 per cent of sugarcane growing area out of 3.00 lakh ha in Bihar is prone to water-logging situation resulting low productivity. Water-logging for the early stage of crop growth affects the germination, tillering and cane growth, which may result in crop failure. Generally, the water-logging coincides with the grand growth phase and may extend up to maturity of the crop and hence, the early planted crop suffers less. Higher water table during active growth phase adversely affects stalk weight and plant population resulting yield loss at the rate of about one tonne per acre for one inch increase in excess water Carter and Floyed (1974), Carter, C. E, (1976). Problem of water-logging area under sugarcane crop is also exist in several parts of country viz, Assam, West Bengal, eastern Uttar Pradesh, Coastal region of Andhra Pradesh, Tamil Nadu, Kerala and 
Karnataka are exposed to stagnant water for two to three months during rainy season. A large difference in varietal response to waterlogging in sugarcane has been reported as we know that varieties differ in degree of tolerance to water-logging based on certain inherent genetic characteristics, age of the crops and other growing conditions. The varieties which were well performer under water-logging situation in Bihar during present investigation (BO91, BO 110 and BO147 covered nearly $40 \%$ areas ) viz, BO 91 and BO 147 were used as check to evaluate water logging tolerant genotype bearing high cane and sugar yield so that best performer varieties will disseminate after replacement of inferior low yielder. The clonal differences in the response of severe water-logging and found that under artificially created conditions of prolonged water-logging clones of Sacchaum barberi, Saccharum sinense, Saccharum sclerostachya and Saccharum erianthus survived. Several clones of Saccharum spontaneum, Saccharum robustum and Saccharum narenga were water-logging tolerant. In the breeding of sugarcane, it has been a general practice to cross the different species with the noble cane, S. officinarum, to combine the high sugar yield of the officinarum clones with hardiness and disease resistance of the other species, a procedure called nobilization. Todays hybrid complexes clones with water-logging tolerant genes can do well under water-logging condition which requires systematic study on their comparative tolerance and knowledge of genetic divergence among the genotypes. Although the use of high yielding varieties coupled with moderate to high sucrose and also having water-logging tolerance capacity contribute substantially in sugarcane production and productivity but still there is need to screen sugarcane varieties tolerant to water-logging condition for its better adaptability after replacement of old /obsolete clones to overcome the problem of water-logging areas under sugarcane cultivation which will enhance the productivity as well as recovery of this crop. Keeping in view of the above facts divergence study in sugarcane plant and ratoon crops and selection of more profitable clones tolerant to water-logging conditions will be helpful for further improvement and selected clone will be profitable to the farmers in term of more yield and fodder for animal feed.

\section{Materials and Methods}

Sixteen sugarcane genotypes viz, BO153, BO141, CoSe 96436, CoX 07067, CoP 081, CoP 091, CoP 02061(CoP 2061), CoP 111, CoP 04181, BO 155, BO 154, BO 146, CoP 092(CoP 9437), CoLk 94184 including two checks namely BO 91 and BO147 were planted in RBD with three replications at Paddy Block, RAU Pusa Farm, Samastipur, Bihar during 2012-2013 and its consecutive ratoon during 2013-14 under low land area and grand growth phages of both the crops coincides with a water stagnation minimum depth of $40-45 \mathrm{~cm}$ for 2 to 3 months. All the recommended agronomical package and practices were followed for respective plant and ratoon crops. In plant crop each replication each genotype's three budded sets were planted at the rate of 12 buds per meter in a plot of 6 rows of 6 meters length and spacing of $90 \mathrm{~cm}$ was maintained between the two rows and it was a net plot size of $32.4 \mathrm{~m}^{2}$. After harvest the plant crop, saving of the each rows were done for raising proper ratoon crop in same situation and same plot size. Cane yield and Juice quality attributing characters were record by selecting five random plants per genotype per replication, during the observation of data for plant as well as ratoon crop. The data from different clones were recorded for various growth and cane yield parameter viz. cane yield ( $\mathrm{t} / \mathrm{ha}$ ), number of millable canes at harvest (000/ha), Plant height $(\mathrm{cm})$, cane diameter $(\mathrm{cm})$, single cane 
weight $(\mathrm{kg})$, no. of shoots (000/ha)120 days and germination $\% 45$ days (in case of plant crop). Cane yield (t/ha) and number of millable canes were recorded at harvest stages of crops. Plant height of five plants were marked from each genotype at different stges viz, 150 days, 240 days and at harvest, measured in centimeter from base to the tip of cane. For cane diameter $(\mathrm{cm})$ same five canes were measure with help of vernier caliper. Single cane weight was also recorded from the same set of five cane used for length and diameter. The mean data of five plants was used for statistical analysis. No. of shoots (000/ha) were recorded at 120 and 240 days old crop while no. of tillers (000/ha) for millable cane was counted at harvest stages. For plant crop germination (\%) at 45 days was calculated from the total no. of bud planted/No. of Germination $\times 100$ while in ratoon observation start from no. of shoots count at 120 days. Juice qualities tests such as brix, pol and purity were done for both the crops at different stages viz, at the 9 month stage ( for ratoon), 10 month stage(Plant Crop), 11 month stage( Plant \& ratoon) and 12 month stage(Plant Crop). Brix \% was measure using a Brix hygrometer. After taken $250 \mathrm{ml}$ juice in measuring cylinder and a hygrometer dip into the juice then reading was recorded from the juice level and these readings were corrected to the temperature at $20{ }^{0} \mathrm{C}$ using temperature correction chart as described by Spencer and Meade (1955). Sucrose per cent in juice (i.e. pol \%) estimated by Spencer and Meade (1955) method with the help of Polari scope. Taken $100 \mathrm{ml}$ juice in conical flask and 4 gm Honey dry lead sub acetate was added and mixed well by shaking the flask. This solution was filtered twice through a dry Whatsman no. 1 filter paper after few minutes and the abstract was collected into a clean and dry beaker. The abstract poured into the Polari meter tube to record the Pol values in Polari scope this value called dial reading. Sucrose per cent in juice was obtained by referring the brix and dial reading to Schmitz's table. After recording brix and pol \% of juice the value of CCS \% was calculated. CCS $(\%)=0.292 \times$ Pol $\%$ juice $(0.035 \times$ Purity \%) -1) / Purity \% X 100 and $\operatorname{CCS}(\mathrm{t} / \mathrm{ha})=\operatorname{CCS}(\%) \times$ Cane yield $(\mathrm{t} / \mathrm{ha})$

For both the plant and ratoon crops among the 16 genotypes of sugarcane, genetic divergence was estimated by analyzing the data of cane yield, juice quality and its attributing traits through $\mathrm{D}^{2}$ statistics (Mahalanobis, 1936) view showed in Fig. 2. The steps start with evaluation of replicated field trials and observed data were used to calculate the Genotypic Variance $\left(\sigma_{\mathrm{g}}{ }^{2}\right)=(\mathrm{vMSS}-\mathrm{EMSS}) \mathrm{x}$ $\mathrm{CF}$ and Phenotypic variance $\left(\sigma_{\mathrm{p}}{ }^{2}\right)=\sigma_{\mathrm{g}}{ }^{2}+$ EMS and $\mathrm{D}^{2}$ Calculation.

Calculation of $\mathrm{D}^{2}$ values by using the formula

$$
\mathrm{D}^{2}=\mathrm{W}_{\mathrm{ij}}\left(\bar{X}_{\mathrm{i}}{ }^{1} \bar{X}_{\mathrm{i}}^{2}\right)\left(\bar{X}_{\mathrm{j}}^{1}-\right.
$$

Where,

$$
\mathrm{W}_{\mathrm{ij}}=\text { Inverse of estimated variance, }
$$
co-variance matrix.

$$
\left(\bar{X}_{\mathrm{i}}{ }^{1}-X_{\mathrm{i}}{ }^{2}\right) \text { and }\left(\bar{X}_{\mathrm{j}}^{1}-\bar{X}_{\mathrm{j}}{ }^{2}\right)=
$$

Differences in the mean of the two populations.

Individual traits contribution towards total divergence was checked out by taking the percentage of number of times each trait ranked first on the basis of

$\mathrm{d}_{\mathrm{i}}=\mathrm{Y}_{\mathrm{i}}^{\mathrm{j}}-\mathrm{Y}_{\mathrm{i}}^{\mathrm{k}}$

Where,

$\mathrm{d}_{\mathrm{i}}=$ Mean deviation in

population

$$
Y_{i}^{j} \text { and } Y_{i}{ }^{k}=\text { Values for trait in }
$$

population

Rank 1 was given to the highest mean difference and ' $p$ ' to the lowest mean differences, where ' $p$ ' is the total number of characters. Using these ranks, a table was prepared to determine the percentage 
contribution of each character to the total divergence.

Various clusters were formed for the grouping of genotypes on the basis of Tocher's methods Rao, (1952). It was carried out in the following steps:

Arrangement of population in ascending order on the basis of their relative distances $\left(D^{2}\right.$ values) from each other

Two populations having small distance from each other were considered first. Then second population having smallest $\mathrm{D}^{2}$ from the first two populations was added to it.

Continued this step until the average increase in $\mathrm{D}^{2}$ value did not exceed the maximum $\mathrm{D}^{2}$ value between any two populations in the first row of the table.

The average intra cluster and inter cluster distance were calculated following the methods of Singh and Chaudhary (1977).

Average intra cluster distance was estimated by using the formula

$$
\sum D_{i}^{2} / n
$$

Where,

$\sum \mathrm{D}_{\mathrm{i}}{ }^{2}=$ the sum of distance between all possible combinations (n) of the population included in a cluster.

Average inter cluster distance was estimated by using the formula

\section{$\sum D_{i}^{2} /\left(n_{1} \times n_{2}\right)$}

Where,

$$
\sum D_{i}^{2}=\text { Sum of distance of all }
$$

possible combinations of genotypes included in the two clusters considered

$\mathrm{n}_{1}=$ Number of genotypes in first cluster

$\mathrm{n}_{2}=$ Number of genotypes in second clusters
A cluster diagram was prepared showing the distances between clusters and genotypes on the basis of methods as explain above.

Observed data of all the quantitative traits after statistical analysis of both the plant and ratoon crops used to genotypes classification in different clusters, results of inter and intra clusters $\mathrm{D}^{2}$ values between clusters, as well as mean of intra-clusters $D^{2}$ values of different clusters were estimated and presented in table no.1-4 and Fig 1-2. Percent increase or decrease in ratoon crops for cane yield and CCS t/ha of all the 16 genotypes were also calculated and again percent increase or decrease over checks (BO91 and BO 147) in both plant and ratoon crops for cane yield and CCS t/ha of all the genotypes under waterlogging condition along with its rank and pooled rank were calculated to find out profitable genotype under water logging situation as presented in table no. 5 and 6 illustrate its results.

\section{Results and Discussion}

The yield and quality effect due to water logging depends upon the genotypes, environmental conditions, stage of development and the duration of stress. Ratoon occupies almost 50 per cent of the total area under sugarcane cultivation and contributes $30 \%$ of the total cane production in the country (Sundara, 2008). The average yield gap between plant and ratoon crop in the country is $20 \%$ - $25 \%$ acted as one of the major bottlenecks in increasing the productivity of ratoon crops in the subtropics is the poor sprouting of stubbles in winterharvested cane another problem related to water logging which is an acute problem particularly, where surface drainage facilities are not adequate. Nutrient uptake is affected under water logging where aerobic respiration by sugarcane root system is poor (Singh, 1990). Furthermore, under longer duration of 
inundation, some morphological, anatomical, physiological and biochemical changes take place in the plant for sake of adaptation and / or survival. The levels of sucrose, glucose and fructose however were found to higher during anaerobic growth, but there was no correlation between sugar levels and flooding tolerance among different plants (Rahman et al., 1985). Diversity analysis helps in assessing the nature of diversity in order to identified genetically diverse genotypes for their use in breeding programmes. In sugarcane breeding programme the diversity of parents must be emphasized for bi-parental/poly crossing. More diverse the parent within a reasonable range, better the chances of improving economic characters under consideration in the resulting offspring. $\mathrm{D}^{2}$ statistic (Mahalnobis's ) is an unique tool for classifying genetically diverse parents based on quantitative traits (Fig.2) which could be appropriately utilized in hybridization programme. In the present investigation comparative clustering pattern of sixteen genotypes for both plant and ratoon crop taken for genetic divergence analysis and found differed significantly with regard to the traits studied and displayed marked divergence and grouped into five clusters following Tocher's method (table 1 and Fig.1) either in plant or ratoon crop. For plant crop Cluster II had eight genotypes namely, CoP 2061, BO146, CoP 04181, BO 141, BO 91, BO 147, BO 154 and CoP 09437 followed by Cluster I consisting five genotypes viz. CoP111, BO 155, BO153, CoLk 94184 and CoP 091, while Cluster III, Cluster IV and Cluster V showed monogenotypic with a single genotype in each cluster in plant crop. Comparison with plant crop similar five clusters were obtained in ratoon crop while the member (genotypes) of clusters differed and change the position clusters, Cluster I had seven clones viz, BO154, CoP 09437, CoP 2061, CoP 091, CoP 111, BO155 and BO141 followed by Cluster II containing six clones viz. CoP 04181,
BO146, BO91, CoSe 96436, CoP 081 \& CoLk 94184 while Cluster III, IV and V were monogenotypic and each cluster was comprising with a single clone BO 147, BO 153 and CoX 07067, respectively. Studies based on $\mathrm{D}^{2}$ statistic was also followed by Ahmed and Obeid (2010), Bakshi and Hemaprabha (2005), Gagan et al. (2005), Hooda et al. (1989), Kashif and Khan (2007), Mali et al. (2009), Mishra et al. (2005), Rao et al. (1985), Silva et al. (2011), Singh and Khan (1990), Singh and Singh. (2002), Singh et al. (1987), Singh et al. (2001), Singh et al. (2004), Agrawal and Kumar (2017) observed few to several clusters as per As perusal of Table no. 2 which includes cluster mean for yield and juice quality traits of plant and ratoon crop separately their five cluster. A comparison of the mean values of all these yield and juice quality traits for different clusters showed considerable differences in both plant and ratoon crop. In plant crop highest mean values was exhibited in Cluster $\mathrm{V}$ for most of the traits viz, number of shoots at 120 days (150.11), plant height at 150 days (202.30), plant height at 240 days (301.22), purity at 12 month stage (92.54), plant height at 360 days (327.37), cane diameter (2.84), single cane weight (0.97) and cane yield (91.28) while no any maximum value was observed in Cluster $\mathrm{V}$ of ratoon crop it means CoX 07067 showed relatively poor ratooner. In plant crop, CoSe 96436 was a single member of Cluster III and it had maximum mean value for juice quality traits viz, brix at 10 month stage (20.20), pol at 10 month stage (17.36), brix at 11 month stage (19.40), pol at 11 month stage (16.66), brix at 12 month stage (19.77) and CCS per cent at harvest (12.02) while in ratoon crop highest mean values recorded for brix percent at $9 \& 11$ month $(20.10 \& 19.95 \%)$, pol percentage in juice at $9 \& 11$ month(17.77 \& 17.55\%), purity at 9 $\& 11$ month stage $(88.35 \& 87.95 \%)$ and CCS $\%$ (12.13) at harvest in Cluster I consisting BO154, CoP 09437, CoP 2061, CoP 091, CoP 
111, BO155 and BO141 genotypes. Therefore it was found that the genotype CoSe 96436 of plant crop had ability to tolerate water logging with best juice quality and it will utilized as a parent of cross combination for further juice quality improvement in sugarcane variety. In raoon crop Cluster II had maximum mean value for number of shoots at 120 days (138680/ha), plant height at 150 days $(159.55 \mathrm{~cm})$, plant height at 240 days $(221.17$ $\mathrm{cm})$, plant height at 330 days (249.61), cane diameter $(2.40 \mathrm{~cm})$, single cane weight $(0.79$ $\mathrm{Kg})$, Cane yield (85.10 t/ha) and CCS t/ha (9.72) therefore the selected best one genotype of this group will be utilized in improvement programme for best ratooner. In plant crop Cluster I had maximum mean value for purity at 11 month stage (87.66), number of millable canes (112.61) and Cluster IV had maximum mean value for purity at 10 month stage (88.95). The mean of intra and inter cluster distances $\left(D^{2}\right)$ under water-logging condition has been presented in Table no.3. for plant and ratoon crop separately. The average distance of intra cluster ranged from 282.75 (Cluster I) to 6760.25 (Cluster II) in plant crop while in ratoon it ranged from 122.23 (Cluster I) to 162.22(cluster II). In plant crop highest value of inter cluster distance was recorded between cluster IV and V (5763.19) followed by cluster III and V (4350.43), cluster I and V (2297.42), cluster II and V (1835.66), cluster II and IV (1752.25), cluster I and IV (1497.59) and cluster II and III (1458.86), cluster III and IV (1047.88) and cluster I and III (740.67) and lowest inter cluster distance was observed between cluster I and II (678.76). In ratoon crop highest inter cluster distance was recorded between cluster II and V (1050.77) followed by cluster III and V (817.02), cluster III and IV (623.84), cluster II and IV (567.85), cluster I and IV (419.80), cluster I and II (319.39) and cluster I and III (253.19). In comparative diversity study genotypes of ratoon crop showed lower genetic distance than the better performed genotype of plant crop due to maximum inter cluster distance between cluster IV and cluster V exhibited high degree of genetic diversity followed by cluster III and cluster V, cluster I and V and cluster II and cluster V, cluster II and IV, cluster I and IV, cluster II and III, cluster III and IV and cluster I and III, thus they may be utilized under inter varietal hybridization programme or transgressive breeding for getting high cane and sugar yielding recombinants. All these results on genetic diversity were in agreement with that of Gulzar et al (2015), Mishra et al. (2005), Singh and Singh. (2002) and Singh et al. (2001). Kashif \& Khan (2007) reported that Metroglyph scatter diagram shows four groups from 14 genotypes of sugarcane. The clustering pattern showed that varieties developed from same institution were noticed to have fallen into different clusters. Further, it can also be seen from the comparative diversity study of cluster that the three genotypes CoP 09437, CoP 2061 and BO 154 falls in cluster I and II of ratoon and plant it means these were closely related to each othe with respect to performance of plant or ratoon crop.

Performance of plant and ratoon crop indicated in Table no. 4 as contribution percentage of each traits towards total divergence under water-logging condition. In plant crop highest contribution for manifestation of genetic divergence was exhibited by cane yield (52.50) followed by CCS per cent at harvest (20.83), pol \% at 11 month stage (9.17), brix \% at 12 month stage (5.00), plant height at 360 days (5.00), NMC (4.17) pol \% at 12 month stage (2.50) while in ratoon crop highest contribution exhibited by pol \% in juice at 9 month $(45.00 \%)$ followed by brix $\%$ at 11 month $(15.00 \%)$, CCS t/ha at harvest (10.83), purity \% at 9 month $(8.33 \%)$ and single cane weight $(7.5 \%)$ and pol $\%$ in juice at 11 month $(5.0 \%)$. 
Table.1 Clustering pattern using $\mathrm{D}^{2}$ statistic of plant and ratoon crops of 16 clones for yield and juice quality traits under waterlogging.

\begin{tabular}{|c|c|l|c|c|l|}
\hline \multicolumn{2}{|c|}{ Clusters of Plant Crop } & \multicolumn{2}{l|}{ Clusters of Ratoon Crop } \\
\hline Sl.No. & $\begin{array}{c}\text { No. of } \\
\text { genotypes }\end{array}$ & Name of Genotypes & Sl.No. & $\begin{array}{c}\text { No. of } \\
\text { genotypes }\end{array}$ & Name of Genotypes \\
\hline I & 5 & $\begin{array}{l}\text { CoP111, BO155, BO153, } \\
\text { CoLk 94184 } \\
\& \text { CoP 091 }\end{array}$ & I & 7 & $\begin{array}{l}\text { BO154, CoP092(CoP 09437), } \\
\text { CoP 02061 (CoP 2061), CoP 111, } \\
\text { BO155, BO141 \& CoP 091 }\end{array}$ \\
\hline II & 8 & $\begin{array}{l}\text { CoP 02061(CoP 2061), BO146, } \\
\text { CoP 04181, BO141, BO91, BO147, } \\
\text { BO154 \& CoP 092 (CoP 09437) }\end{array}$ & II & 6 & $\begin{array}{l}\text { BO146, BO91, CoP 04181, } \\
\text { CoLk 94184, } \\
\text { CoSe 96436 \& CoP 081 }\end{array}$ \\
\hline III & 1 & CoSe 96436 & III & 1 & BO 147 \\
\hline IV & 1 & CoP 081 & IV & 1 & BO153 \\
\hline V & 1 & CoX 07067 & V & 1 & CoX 07067 \\
\hline
\end{tabular}


Table.2 Cluster mean of (i)Plant \& (ii)Ratoon crops for yield and juice quality traits under water-logging condition.

\begin{tabular}{|c|c|c|c|c|c|c|c|c|c|c|c|c|c|c|c|c|c|c|c|c|}
\hline \multirow[t]{4}{*}{$\begin{array}{c}\text { (i) } \\
\text { Plant Crop }\end{array}$} & \multicolumn{5}{|c|}{ Yield attributing traits } & \multicolumn{11}{|c|}{$\begin{array}{c}\text { Juice quality and attributing traits (\%) } \\
\text { Brix(B), Pol(P), Purity (PU) \& Commercial Cane Sugar(CCS) }\end{array}$} & \multicolumn{4}{|c|}{ Yield \& its attributing traits } \\
\hline & \multirow{3}{*}{$\begin{array}{c}\text { Germi } \\
- \\
\text { nation } \\
\% 45\end{array}$} & \multirow{3}{*}{$\begin{array}{c}\text { Shoots } \\
\text { at } \\
120\end{array}$} & \multicolumn{3}{|c|}{ Plant Height at Days } & \multicolumn{3}{|c|}{ At 10 Month stage } & \multicolumn{3}{|c|}{ At 11 Month stage } & \multicolumn{3}{|c|}{ At 12 Month stage } & \multicolumn{2}{|c|}{$\mathrm{CCS}$} & \multirow{3}{*}{$\begin{array}{l}\text { CD } \\
\text { cm }\end{array}$} & \multirow{3}{*}{$\begin{array}{c}\text { SCW } \\
\text { Kg }\end{array}$} & \multirow{3}{*}{$\begin{array}{l}\text { NMC } \\
\text { 000/ha }\end{array}$} & \multirow{3}{*}{$\begin{array}{l}\text { Cant } \\
\text { Yield } \\
\text { t/ha }\end{array}$} \\
\hline & & & 150 & 240 & 360 & В\% & $\mathbf{P} \%$ & PU\% & B\% & $\mathbf{P \%}$ & PU\% & B\% & $\mathbf{P} \%$ & PU\% & $\%$ & t/ha & & & & \\
\hline & & & & & & & & & & & & & & & & & & & & \\
\hline Cluster I & 33.59 & 137.63 & 156.06 & 196.39 & 229.45 & 17.20 & 15.04 & 87.56 & 18.56 & 16.25 & 87.66 & 17.06 & 14.99 & 88.01 & 10.3 & 7.9 & 2.42 & 0.69 & 112.61 & 76.54 \\
\hline Cluster II & 31.40 & 110.59 & 159.95 & 188.58 & 224.34 & 17.30 & 15.02 & 87.40 & 17.37 & 15.12 & 87.34 & 17.63 & 14.82 & 84.17 & 10. & 8.2 & 2.66 & 0.82 & 100.57 & 82.46 \\
\hline Cluster III & 32.87 & 128.50 & 174.50 & 210.40 & 235.91 & 20.20 & 17.36 & 86.64 & 19.40 & 16.66 & 86.04 & 19.77 & 17.41 & 88.70 & 12.0 & 101 & 2.33 & 0.81 & 104.06 & 84.17 \\
\hline Cluster IV & 33.99 & 132.81 & 173.42 & 207.73 & 238.37 & 18.60 & 16.42 & 88.95 & 18.55 & 16.12 & 87.20 & 18.18 & 15.71 & 87.00 & 10.8 & 9.5 & 2.72 & 0.91 & 97.35 & 88.07 \\
\hline Cluster V & 36.59 & 150.11 & 202.30 & 301.33 & 327.37 & 17.30 & 14.88 & 86.02 & 18.53 & 15.10 & 81.54 & 18.03 & 16.67 & 92.54 & 11.8 & 10.7 & 2.84 & 0.97 & 94.10 & 91.28 \\
\hline
\end{tabular}

\begin{tabular}{|c|c|c|c|c|c|c|c|c|c|c|c|c|c|c|c|c|}
\hline \multirow{3}{*}{$\begin{array}{c}\text { (ii) } \\
\text { Ratoon } \\
\text { Crop }\end{array}$} & \multicolumn{4}{|c|}{ Yield attributing traits } & \multicolumn{8}{|c|}{$\begin{array}{c}\text { Juice quality and attributing traits (\%) } \\
\text { Brix(B), Pol(P), Purity (PU) \& Commercial Cane } \\
\text { Sugar(CCS) }\end{array}$} & \multicolumn{4}{|c|}{ Yield \& its attributing traits } \\
\hline & \multirow{2}{*}{$\begin{array}{c}\text { Shoots } \\
\text { 000/ha } \\
\text { at } 120 \text { Days }\end{array}$} & \multicolumn{3}{|c|}{ Plant Height at Days } & \multicolumn{3}{|c|}{ At 9 Month stage } & \multicolumn{3}{|c|}{ At 11 Month stage } & \multicolumn{2}{|c|}{ CCS } & \multirow{2}{*}{$\begin{array}{l}\text { CD } \\
\text { cm }\end{array}$} & \multirow{2}{*}{$\begin{array}{c}\text { SCW } \\
\text { Kg }\end{array}$} & \multirow{2}{*}{$\begin{array}{l}\text { NMC } \\
\text { 000/ha }\end{array}$} & \multirow[t]{2}{*}{ Cane Yield t/ha } \\
\hline & & 150 & 240 & 300 & B\% & $\mathbf{P \%}$ & PU\% & В\%11 & P\%11 & PU\%11 & $\%$ & t/ha & & & & \\
\hline Cluster I & 117.72 & 145.93 & 198.89 & 230.74 & 20.10 & 17.77 & 88.35 & 19.95 & 17.55 & 87.95 & 12.13 & 9.14 & 2.24 & 0.69 & 107.84 & 75.25 \\
\hline Cluster II & 138.68 & 159.55 & 221.17 & 249.61 & 19.20 & 16.91 & 88.07 & 19.03 & 16.61 & 87.23 & 11.42 & 9.72 & 2.40 & 0.79 & 111.44 & 85.10 \\
\hline Cluster III & 97.29 & 125.19 & 155.72 & 175.16 & 19.00 & 16.81 & 88.33 & 18.70 & 16.59 & 87.73 & 11.50 & 6.71 & 2.06 & 0.62 & 101.47 & 62.71 \\
\hline Cluster IV & 120.46 & 131.97 & 199.62 & 217.06 & 18.47 & 15.93 & 86.67 & 18.13 & 15.65 & 87.13 & 10.70 & 8.43 & 2.16 & 0.66 & 116.31 & 78.70 \\
\hline Cluster V & 102.76 & 138.32 & 169.17 & 197.19 & 18.35 & 16.10 & 87.88 & 16.93 & 14.71 & 86.75 & 10.09 & 5.39 & 2.17 & 0.59 & 90.48 & 53.04 \\
\hline
\end{tabular}

Symball: Brix -(B), Pol- (P), Purity -(PU), Commercial Cane Sugar-(CCS),Number of millable canes - (NMC), Cane Diameter- (CD), Single cane Weight-(SCW) 
Table.3 Mean intra \& inter cluster $\mathrm{D}^{2}$ distance of five clusters of (i)Plant and (ii) Ratoon crops under water logging condition.

\begin{tabular}{|c|c|c|c|c|c|c|}
\hline (i) Plant Crop & & Cluster I & Cluster II & Cluster III & Cluster IV & Cluster V \\
\cline { 2 - 7 } & Cluster I & 282.75 & 678.76 & 740.67 & 1497.59 & 2297.42 \\
\hline & Cluster II & & 6760.25 & 1458.86 & 1752.25 & 1835.66 \\
\hline & Cluster III & & & 0.00 & 1047.88 & 4350.43 \\
\hline & Cluster IV & & & & 0.00 & 5763.19 \\
\hline & Cluster V & & & & & 0.00 \\
\hline
\end{tabular}

\begin{tabular}{|c|l|c|c|c|c|c|}
\hline (ii) Ratoon Crop & & Cluster I & Cluster II & Cluster III & Cluster IV & Cluster V \\
\cline { 2 - 7 } & Cluster I & 122.23 & 319.39 & 253.19 & 220.14 & 419.80 \\
\hline & Cluster II & & 162.22 & 230.54 & 567.85 & 1050.77 \\
\hline & Cluster III & & & 0.00 & 623.84 & 817.02 \\
\hline & Cluster IV & & & 0.00 & 196.47 \\
\hline & Cluster V & & & & & 0.00 \\
\hline
\end{tabular}


Table.4 Contribution percentage of nineteen characters towards genetic divergence in sugarcane under water-logging condition

\begin{tabular}{|c|c|c|c|c|c|}
\hline \multirow{2}{*}{$\begin{array}{l}\text { Sr. } \\
\text { No. }\end{array}$} & \multirow{2}{*}{ Characters } & \multicolumn{2}{|c|}{ Plant Crop } & \multicolumn{2}{|c|}{ Ratoon Crop } \\
\hline & & $\begin{array}{l}\text { Times Ranked } \\
1^{\text {st }}\end{array}$ & $\begin{array}{l}\text { Contribution } \\
\%\end{array}$ & $\begin{array}{l}\text { Contribution } \\
\%\end{array}$ & $\begin{array}{l}\text { Times } \\
\text { Ranked } 1^{\text {st }}\end{array}$ \\
\hline 1 & Germination at 45 days (\%) & 0.001 & 0.00 & ---- & ---- \\
\hline 2 & $\begin{array}{l}\text { No. of shoots at } 120 \text { days ( } \\
\text { 000/ha) }\end{array}$ & 1 & 0.83 & 0.01 & 0.001 \\
\hline 3 & Plant height at 150 days $(\mathrm{cm})$ & 0.001 & 0.00 & 0.01 & 0.001 \\
\hline 4 & Plant height at 240 days $(\mathrm{cm})$ & 0.001 & 0.00 & 4.17 & 5.000 \\
\hline 5 & $\begin{array}{l}\text { Brix at } 9 \text { or } 10 \text { month stage } \\
(\%)\end{array}$ & 0.001 & 0.00 & 0.01 & 0.001 \\
\hline 6 & Pol at 9 or 10 month stage $(\%)$ & 0.001 & 0.00 & 45.00 & 54.000 \\
\hline 7 & $\begin{array}{l}\text { Purity at } 9 \text { or } 10 \text { month stage } \\
(\%)\end{array}$ & 0.001 & 0.00 & 8.33 & 10.000 \\
\hline 8 & Brix at 11 month stage (\%) & 0.001 & 0.00 & 15.00 & 18.000 \\
\hline 9 & Pol at 11 month stage (\%) & 11 & 9.17 & 5.00 & 6.000 \\
\hline 10 & Purity at 11 month stage (\%) & 0.01 & 0.00 & 2.50 & 3.000 \\
\hline 11 & Brix at 12 month stage (\%) & 6 & 5.00 & ---- & ------ \\
\hline 12 & Pol at 12 month stage $(\%)$ & 3 & 2.50 & ---- & ------ \\
\hline 13 & Purity at 12 month stage (\%) & 0.01 & 0.00 & ---- & ------ \\
\hline 14 & CCS per cent at harvest (\%) & 25 & 20.83 & 0.01 & 0.001 \\
\hline 15 & CCS per $\mathrm{t} / \mathrm{ha}$ at harvest & 0.001 & 0.01 & 10.83 & 13.000 \\
\hline 16 & Plant height at harvest $(\mathrm{cm})$ & 6 & 5.00 & 0.01 & 0.001 \\
\hline 17 & Cane diameter at harvest $(\mathrm{cm})$ & 0.01 & 0.00 & 0.83 & 1.000 \\
\hline 18 & Single cane weight (kg) & 0.01 & 0.00 & 7.50 & 9.000 \\
\hline 19 & No. of millable canes $(000 /$ ha) & 5 & 4.17 & 0.01 & 0.001 \\
\hline 20 & Cane yield (tonne/ ha) & 63 & 52.50 & 0.83 & 1.000 \\
\hline
\end{tabular}


Table.5 Percent increase or decrease in ratoon crops for cane yield and CCS t/ha of 16 genotypes under water-logging condition.

\begin{tabular}{|c|c|c|c|c|c|c|c|c|c|c|c|c|c|}
\hline \multirow{2}{*}{$\begin{array}{l}\text { SI. } \\
\text { No. }\end{array}$} & \multirow[t]{2}{*}{ Genotypes } & \multicolumn{6}{|c|}{ Cane yield $\mathrm{t} / \mathrm{ha}$} & \multicolumn{5}{|c|}{$\operatorname{CCS}(t / h a)$} & \multirow{2}{*}{$\begin{array}{c}\text { Pooled } \\
\text { Rank } \\
\text { Cane Yield } \\
\text { and } \\
\text { CCS t/ha }\end{array}$} \\
\hline & & Plant & Ratoon & $\begin{array}{l}\text { \% loss in } \\
\text { ratoon } \\
\text { over plant } \\
\text { crop }\end{array}$ & Mean & $\begin{array}{c}\% \\
\text { Contribution } \\
\text { of } \\
\text { ratoon on } \\
\text { mean }\end{array}$ & Rank & Plant & Ratoon & $\begin{array}{l}\text { \% increase } \\
\text { or decrease } \\
\text { over plant }\end{array}$ & $\begin{array}{l}\text { Average } \\
\text { of Plant } \\
\text { \& Ratoon }\end{array}$ & Rank & \\
\hline 1. & BO153 & 78.51 & 69.81 & -11.10 & 74.16 & 47.1 & 5 & 8.69 & 8.38 & -03.57 & 8.54 & 4 & 4.5 \\
\hline 2. & BO141 & 72.56 & 60.12 & -17.14 & 66.34 & 45.4 & 12 & 6.89 & 7.17 & +03.05 & 7.03 & 2 & 7 \\
\hline 3. & CoSe96436 & 62.81 & 52.49 & -16.43 & 57.65 & 45.6 & 11 & 7.48 & 5.23 & -30.10 & 6.34 & 14 & 12.5 \\
\hline 4. & CoX 07067 & 91.28 & 80.69 & -11.6 & 85.99 & 47.0 & 6 & 10.74 & 9.89 & -07.91 & 10.32 & 8 & 6.5 \\
\hline 5. & CoP081 & 82.96 & 62.28 & -24.93 & 72.62 & 43.0 & 14 & 7.61 & 6.91 & -07.20 & 7.26 & 6 & 10 \\
\hline 6. & CoP091 & 81.05 & 70.12 & -13.49 & 75.56 & 46.5 & 8 & 9.60 & 7.95 & -17.18 & 8.78 & 12 & 10 \\
\hline 7. & CoP 2061 & 92.68 & 84.28 & -09.10 & 88.48 & 47.6 & 2 & 8.75 & 9.52 & +08.80 & 9.14 & 1 & 1.5 \\
\hline 8. & CoP111 & 91.37 & 80.32 & -12.10 & 85.85 & 46.8 & 7 & 9.37 & 8.75 & -06.61 & 9.06 & 5 & 6 \\
\hline 9. & CoP 04181 & 71.44 & 50.48 & -29.34 & 60.96 & 41.4 & 15 & 7.04 & 5.60 & -20.45 & 6.32 & 13 & 14 \\
\hline 10. & BO155 & 94.45 & 81.50 & -13.71 & 87.98 & 46.3 & 9 & 9.79 & 8.92 & -08.89 & 9.36 & 7 & 8.5 \\
\hline 11. & BO154 & 97.08 & 83.47 & -14.01 & 90.28 & 46.2 & 10 & 11.27 & 9.63 & -14.45 & 10.45 & 11 & 10.5 \\
\hline 12. & BO146 & 81.46 & 40.46 & -50.33 & 60.96 & 33.2 & 16 & 8.22 & 4.21 & -48.78 & 6.22 & 16 & 16 \\
\hline 13. & CoP09437 & 96.12 & 87.54 & -8.93 & 91.83 & 47.7 & 1 & 11.19 & 10.00 & -10.63 & 10.60 & 9 & 5 \\
\hline 14. & $\begin{array}{c}\text { CoLk } \\
94184\end{array}$ & 72.22 & 58.32 & -19.24 & 65.27 & 44.7 & 13 & 8.95 & 4.80 & -46.36 & 6.88 & 15 & 14 \\
\hline 15. & BO $91(\mathrm{C})$ & 76.22 & 68.72 & -10.38 & 72.47 & 47.4 & 4 & 8.02 & 6.52 & -11.50 & 7.27 & 10 & 7 \\
\hline 16. & $\mathrm{BO} 147(\mathrm{C})$ & 82.17 & 74.28 & -09.60 & 78.23 & 47.5 & 3 & 7.40 & 7.61 & +02.84 & 7.51 & 3 & 3 \\
\hline & Mean & 82.77 & 69.06 & -16.60 & 75.92 & 45.5 & - & 8.81 & 7.57 & -14.10 & 8.16 & -- & -- \\
\hline
\end{tabular}

Higher \% contribution of ratoon towards average mean and \% loss (minimum) indicates ranked first, Pooled rank $=($ Rank for cane yield + Rank for CCS $t /$ ha $) / 2$ 
Table.6 Percent increase or decrease over checks (BO91 and BO 147) in plant and ratoon crops for cane yield and CCS t/ha of 16 genotypes under water-logging condition along with its rank and pooled rank.

\begin{tabular}{|c|c|c|c|c|c|c|c|c|c|c|c|c|c|c|}
\hline \multirow{3}{*}{$\begin{array}{l}\text { Sl. } \\
\text { No. }\end{array}$} & \multirow[t]{3}{*}{ Genotypes } & \multicolumn{6}{|c|}{ Cane yield $t / h a$} & \multicolumn{6}{|c|}{ Commercial Cane Sugar (t/ha) } & \multirow{3}{*}{$\begin{array}{c}\text { Profitable } \\
\text { Pooled } \\
\text { Rank }\end{array}$} \\
\hline & & \multicolumn{3}{|c|}{ Crops and Mean } & \multicolumn{3}{|c|}{$\begin{array}{c}\text { \% increase/decrease over } \\
\text { checks and rank }\end{array}$} & \multicolumn{3}{|c|}{ Crops and Mean } & \multicolumn{3}{|c|}{$\begin{array}{c}\% \text { increase/decrease over } \\
\text { checks and rank }\end{array}$} & \\
\hline & & Plant & Ratoon & Mean & BO 91 & $\begin{array}{l}\text { BO } \\
147\end{array}$ & Rank & Plant & Ratoon & Mean & BO 91 & BO 147 & Rank & \\
\hline 1. & BO153 & 78.51 & 69.81 & 74.16 & 2.3 & -05.20 & 8 & 8.69 & 8.38 & 8.54 & 17.45 & 13.72 & 8 & 8 \\
\hline 2. & BO141 & 72.56 & 60.12 & 66.34 & -8.5 & -15.20 & 10 & 6.89 & 7.17 & 7.03 & -03.30 & -06.39 & 10 & 10 \\
\hline 3. & CoSe96436 & 62.81 & 52.49 & 57.65 & -20.5 & -26.31 & 13 & 7.48 & 5.23 & 6.34 & -12.80 & -15.58 & 12 & 12.5 \\
\hline 4. & CoX 07067 & 91.28 & 80.69 & 85.99 & 18.7 & 09.92 & 5 & 10.74 & 9.89 & 10.32 & 41.95 & 37.42 & 3 & 4 \\
\hline 5. & CoP081 & 82.96 & 62.28 & 72.62 & 0.2 & -07.17 & 9 & 7.61 & 6.91 & 7.26 & -00.14 & -03.33 & 9 & 9 \\
\hline 6. & CoP091 & 81.05 & 70.12 & 75.56 & 4.3 & -03.41 & 7 & 9.60 & 7.95 & 8.78 & 20.77 & 16.91 & 7 & 7 \\
\hline 7. & CoP 2061 & 92.68 & 84.28 & 88.48 & 22.1 & 13.10 & 3 & 8.75 & 9.52 & 9.14 & 25.72 & 21.70 & 5 & 4 \\
\hline 8. & CoP111 & 91.37 & 80.32 & $\mathbf{8 5 . 8 5}$ & 18.5 & 09.74 & 6 & 9.37 & 8.75 & 9.06 & 24.26 & 20.64 & 6 & 6 \\
\hline 9. & CoP 04181 & 71.44 & 50.48 & 60.96 & -15.9 & -22.08 & 12 & 7.04 & 5.60 & 6.32 & -13.10 & -15.85 & 13 & 12.5 \\
\hline 10. & BO155 & 94.45 & 81.50 & 87.98 & 21.4 & 12.50 & 4 & 9.79 & 8.92 & 9.36 & 28.75 & 24.63 & 4 & 4 \\
\hline 11. & BO154 & 97.08 & 83.47 & 90.28 & $24.6 \%$ & 15.40 & 2 & 11.27 & 9.63 & 10.45 & 43.74 & 39.14 & 2 & 2 \\
\hline 12. & BO146 & 81.46 & 40.46 & 60.96 & $-15.9 \%$ & $-22.1 \%$ & 12 & 8.22 & 4.21 & 6.22 & -14.44 & -17.18 & 14 & 13 \\
\hline 13. & CoP092 & 96.12 & 87.54 & 91.83 & $26.7 \%$ & $17.4 \%$ & 1 & 11.19 & 10.00 & 10.60 & 45.80 & 41.15 & 1 & 1 \\
\hline 14. & CoLk 94184 & 72.22 & 58.32 & 65.27 & $-9.9 \%$ & $-16.6 \%$ & 11 & 8.95 & 4.80 & 6.88 & -05.37 & -08.39 & 11 & 11 \\
\hline 15. & BO $91(C)$ & 76.22 & 68.72 & 72.47 & --- & & & 8.02 & 6.52 & 7.27 & - & & & \\
\hline 16. & $\mathrm{BO} 147(\mathrm{C})$ & 82.17 & 74.28 & 78.23 & --- & & & 7.40 & 7.61 & 7.51 & - & & & \\
\hline
\end{tabular}

$\%$ increase/decrease over checks (BO 91 and BO147) and \% loss (minimum) indicates ranked first, Pooled rank $=($ Rank for cane yield + Rank for CCS t/ha)/2 
Fig.1. Clustering pattern of 16 sugarcane genotypes on the basis of $\mathrm{D}^{2}$ statistic by Tocher method for cane and juice quality trait
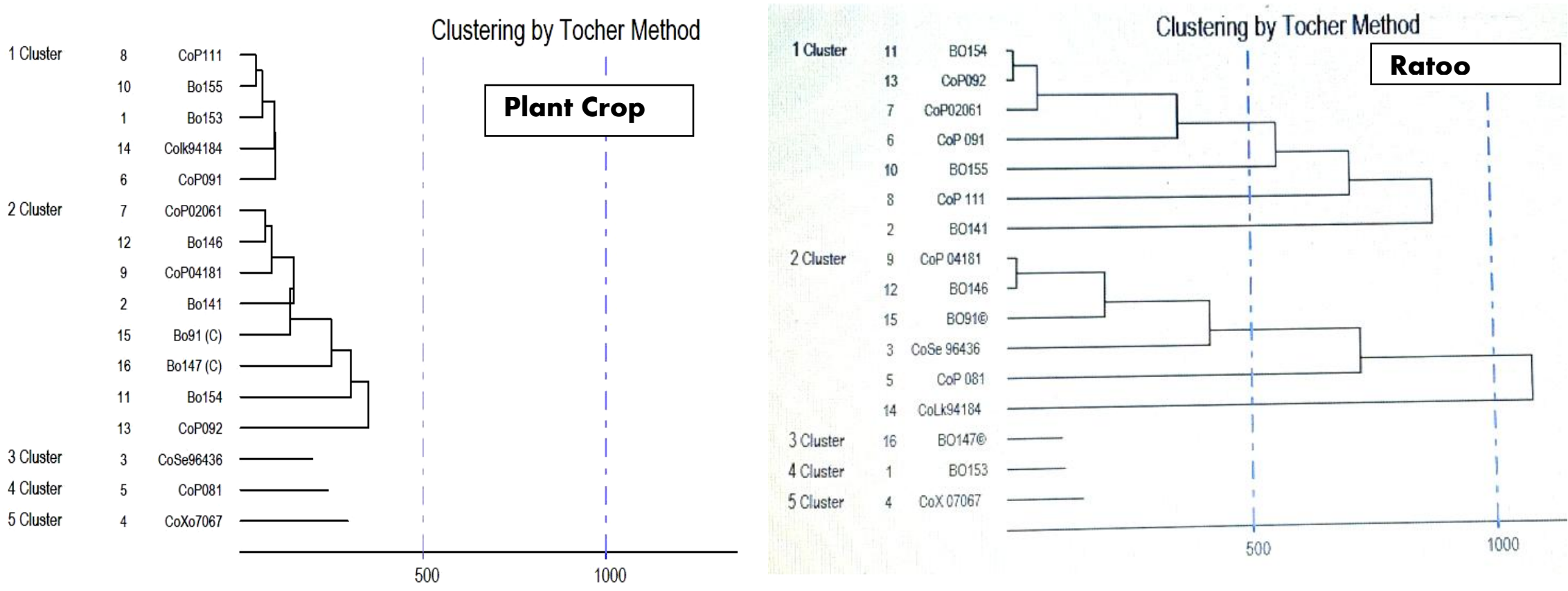
Fig. 2 Mahalnobis Euclidean Disatnce $\left(\mathbf{D}^{2}\right)$ among the 5 Clusters of Plant and Ratoon Crops involving 16 sugarcane genotypes.

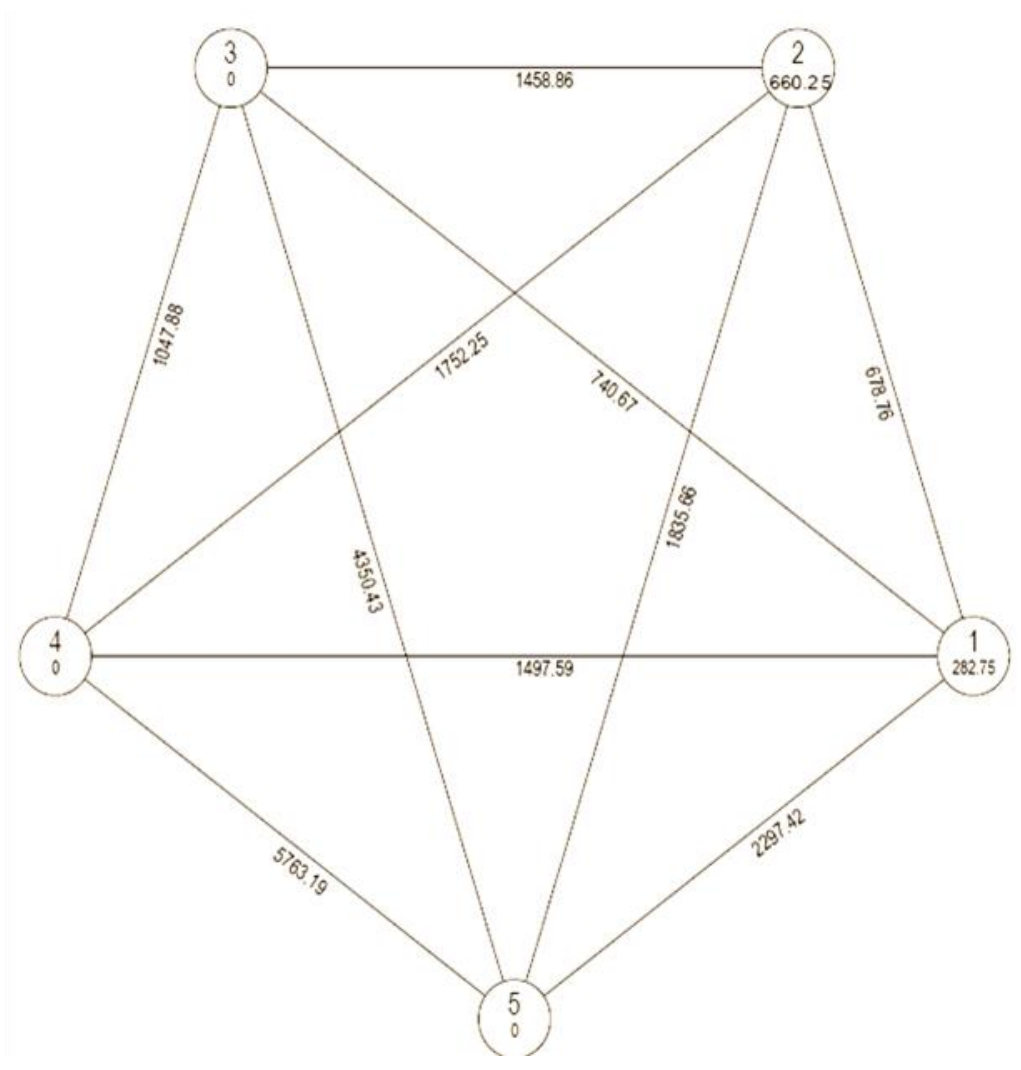

Plant Crop

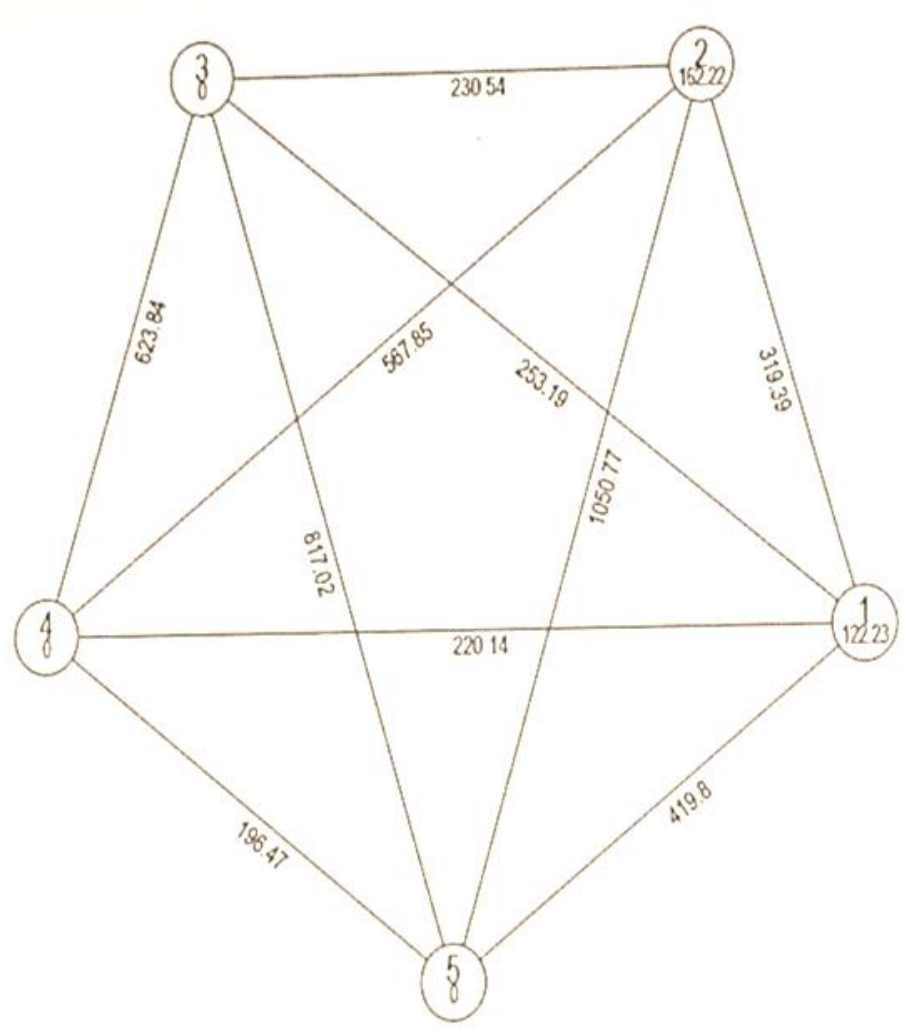

Ratoon Crop 
Percentage increase or decrease in ratoon crop on average productivity and increase or decrease over checks were calculated and presented in Table no. 5 and 6 for identification of profitable genotype. Average of both crops maximum cane yield (91.83 t/ha) and CCS t/ha (10.60 t/ha) were recorded in CoP 09437 followed by BO 154, CoP 2061, BO 155 and CoX 07067. Kumar et al. (2015) reported CoP 2061- a released and notified midlate maturing sugarcane variety for Bihar, Eastern Uttar Pradesh, Assam and West Bengal ant it will replac BO 91 in coming years through its high yied and adaptability in subtropical as well as tropical condition due to stress tolerance ability. In another study Kumar et al.(2016) also reported CoP 09437 an identified sugarcane variety and a better option for high yielding under North Central and North Eastern Zones of India, its performance showed at par with CoP 2061 and BO 154. As per present investigation these three genotypes had also water logging tolerance ability and profitable for farmers as well as sugar mills. The minimum average yield gap between plant and ratoon crop was observed in CoP 09437(losses 8.93\%) followed by CoP 2061( loss 9.10\%)while a wide range was found (loss 50.33 to $8.93 \%$ ) in percentage loss among the genotypes. As we know productivity of plant and ratoon crop refelect average yield, therefore contribution of both crops must be high. In present investigation ratoon crops contribution range from 33.2 to $47.7 \%$ towards average production. Highest contribution of ratoon productivity towards average cane yield of CoP 09437(91.83 t/ha) was recorded $47.7 \%$ and got top rank for profitable as per economic point of view. The CoP 09437 had 26.7 and $17.4 \%$ higher cane yield than checks viz, BO91 \& BO147, respectively followed by BO 154 and CoP 2061. Again CoP 09437 had 45.80 and $41.15 \%$ higher CCS t/ha than the BO 91 and BO 147, respectively followed by BO 154 and CoP 2061. Selection on the basis of percentage increase over checks and minimum loss in cane yield and CCS t/ha the genotypes namely, CoP 09437, BO 154 and CoP 2061 were found profitable one to cultivate under low land (water logging) sugarcane growing areas of Bihar to enhance productivity and sugar recovery.

Conclusion of the comparative study diversity reveled that cross combination between cluster I \& V and Cluster II \& V will get high cane and sugar yield coupled with tolerance to water logging for plant as well as ratoon crop. The genotype CoSe showed high juice quality and CoX 07067 having high yield along with tolerant to water logging may be used as a parent in crossing programme for further Improvement. Genotypes CoP 09437, BO154 and $\mathrm{CoP} 2061$ were better for plant as well as ratoon but closely related to one another may be used as parent for cross with above high juice quality genotype or high yielder one so that it will fulfill to get high yielder coupled with high sugared clones tolerant to water logging ability. More profitable genotype have less than $10 \%$ loss in their ratoon cane and sugar yield with high mean in plant, ratoon and average of both. Finally CoP 09437, BO154 and CoP 2061 were performed better and selected as water-logging tolerant genotypes will be useful for sugarcane farmers to get high yield in water logging situation and other hand sugar mills to get more sugar recovery as well as its diversity studies and selection procedure will also helpful for further sugarcane researchers.

\section{References}

Agrawal, R. K. and Kumar B.(2017) Genetic Divergence in Sugarcane under WaterLogging

Condition and Identification of Tolerant Clones. Int.J.Curr.Microbiol.App.Sci. 6(7): 4044-4055.

Ahmed, A. O. and Obeid, A. (2010). Genetic 
divergence among sugarcane genotypes (Saccharum spp.) for

cane yield attributes and quality determinants. African Journal of Agricultural Research. 5(16): 21032107.

Bakshi, Ram and Hemaprabha, G. (2005). Genetic divergence of sugar yield and its components in flowering type Saccharum officinarum clones. Agric. Sci. Dig. 25(2): 118-120.

Carter, C.E. and Floyed, J.M. (1974). Inhibition of sugarcane yields by high water level during dormant season. Proc. Soc. Sug. Cane Technol., 4: 1418.

Carter, C.E. (1976). Excess water decreases cane and sugar yields. Proc. Am. Soc. Cane Technol., 6: 44-51

Chapman, L.S.,R. Ferraris and M.M. Ludlow(1992). Ratooning ability of cane varieties, variation in yield and yield components, Proceedings of Australian society Sugar Technology, 14:130-138.

Gagan, Deep, Mehla, A. S., Punia, M. S. and Kadian, S. P. (2005). Studies on genetic divergence in sugarcane. Indian Sugar. 55(9): 79-84.

Gulzar Sanghera, S., Kumar, R., Tyagi, V., Thind, K. S. and Sharma, B. (2015). Genetic divergence among elite sugarcane clone (Saccharum officinarum L.) based on cane yield and quality traits from northern India. Journal of Experimental Biology and Agricultural Sciences, April - 2015; Volume - 3(2) 184-190.

Hooda, M. S., Singh, S. and Chaudhary, B. S. (1989). Genetic divergence studies in sugarcane. Haryana Agric. J. Res. 19(3): 249-252.

Kang SA, Noor M, Khan FA, Saeed F (2013) Divergence analysis and association of some economical characters of sugarcane (Saccharum officinarum
L.).Journal of Plant Breeding and Genetics.1:01-06

Kashif, M. and Khan FA (2007) Divergence in sugarcane (Saccharum officinarum L.) based on yield and quality traits. Pakistan Journal of Botany 39: 1559-1563.

Kumar, B., Kamat., D.N. and Pandey, S.S.(2016) CoP 09437 - An identified sugarcane variety and a better option for high yielding under North Central and North Eastern Zones of India. Indian Journal of Sugarcane Technology31(02): 50-54.

Kumar, B., Kamat., D.N. and Pandey, S.S.(2015) CoP 2061.- A released and notified midlate maturing

sugarcane variety for Bihar, Eastern Uttar Pradesh, Assam and West Bengal Indian Journal of Sugarcane Technology 30(02): 63-66.

Mahalanobis, P.C., (1936). On the generalised distance in statistics. Proceedings of National Institute of Science, India, 2: 49-55.

Mishra, P. K., Ashok Mishra. and Prasannajit Mishra. (2005). Genetic divergence in sugarcane. Indian Sugar. 55(5): 33-38.

Nair, N.V. (2012) Sugarcane genetic resources status ,Potential and role insugarcane improvement Journal of Sugarcane Research 2(2) 1-8.

Rao, C.R. (1952) Advanced biometrical methods in biometric research. John Wiley and Sons Inc. New York. pp 357-363.

Singh, R. K., Chaudhary, B. D. (1977)Biometrical methods in quantitative genetic analysis, New Delhi, India : Kalyani Publishers, 1977.

Singh, H. N., Rai, J. N. and Vishwakarma, R. S. (1987). Genetic divergence in sugarcane (Saccharum hybrid species). Indian Sugar Crops Journal. 13(2-3): 1-4. 
Singh, P. K., Sanjeev Kumar. and Singh, J. (2004). Genetic divergence in Saccharum spp. germplasm under subtropics. Indian Sugar. 53(11): 903906.

Singh, P. K., Singh, J., Sanjeev Kumar. and Pandey, D. K. (2004). Genetic divergence in commercial hybrids of sugarcane (Saccharum spp. hybrids). Cooperative Sugar. 35(11): 861-863

Singh, S.and Khan, A. Q. (1990). Genotypic diversity in sugarcane. Crop Improvement. 17(1): 13-16
Singh, P.and Singh, V.P. (2002) Genetic divergence in sugarcane germplasm. Indian Journal of Agricultural Sciences 72: $252-253$.

Sunddra, B (2008) Sugarcane ratoon ,their importance and Establishment. In: T. R. Shanthy and Prathap, Eds., Ratoon management in sugarcane, SBI, Coimbatore. Pp. 6-11.

Walker DIT(1987) Manipulating the genetic b ase of sugarcane. In: Copersucar Int Sugarcane Breed Worksh. Copersucar, Sao Paulo, pp 321-334.

\section{How to cite this article:}

Balwant Kumar, D. N. Kamat, and Singh S. P. 2019. Diversity Studies in Plant and Ratoon Crops for Selection of Profitable Sugarcane Genotypes Tolerant to Water Logging. Int.J.Curr.Microbiol.App.Sci. 8(09): 1928-1945. doi: https://doi.org/10.20546/ijcmas.2019.809.223 